\title{
Correlation between lipid profile and serum cortisol during examination stress among I MBBS students
}

\section{Tangeda Padmaja Rao}

\author{
Associate Professor, Department of Physiology, Prathima Institute of Medical Sciences Nagunur, Karimnagar, Telangana, \\ India. Kprao2011@yahoo.com
}

Corresponding author: Dr. Tangeda Padmaja Rao, Department of Physiology, Prathima institute of Medical sciences, Nagnur, Karimnagar, Telangana

DOI : 10.47799/pimr.0802.05

\section{ABSTRACT}

Background: Stress is an important mental health problem which significantly affects the medical under graduates. Cortisol is known as stress hormone. Medical education is very stressful out of all higher education and medical undergraduates are more affected when compared to other professional students. In that examination has been described as a naturalistic stressor capable of affecting human health.

Objectives : To estimate and correlate serum cortisol and lipid profile before \& during the examination in medical students.

Materials \& Methods: A longitudinal follow up study was done on 50 first MBBS students(aged,18-25 years) of Prathima college after taking informed consent. Subjects were assessed for stress parameters with given questionnaire of 42 items(DASS-42) and serum cortisol, lipid profile at two times. Exactly $5 \mathrm{ml}$ of venous blood was collected from each subject before \& during major examination for cortisol \& lipid profile. Cortisol was assessed using ELISA techniques, while lipid parameters were assessed using standard enzymaticspectrophotometric methods.

Results: There was statistically significant increase in serum cortisol, Total cholesterol, HDL-cholesterol and LDL-cholesterol levels in students during examination stress compared to the before examination period $(P=0.001,0.001,0.001,0.005$ and 0.001 , respectively). There was also non significant positive correlation between serum cortisol and other lipid profile parameters before examination stress but not during the examination period.

Conclusion: Significant increase in cortisol, TC, HDL and LDL but no significant correlation between cortisol and the other parameters were observed during examination stress. This study could be helpful to the students in planning strategies to be adopted to cope up the examination stress to prevent harzards of stress..

Keywords: Examination stress, cortisol, lipid profile Introduction

Stress is an important mental health problem which significantly affects the medical under graduates. Perceiving a course in the medicine is challenging and demands lot of hard work and dedication. First MBBS students who enter the medical school have to deal with the vast syllabus, lack of time and large expectations from parents, peers and teachers; which expose them to varied types of stresses. Stress is defined as "a physical or psychological stimulus that can produce mental or physiological reactions that may lead to illness" 1 .

When compared to global population the prevalence of depression and anxiety is lesser in medical undergraduates of Asia ${ }^{2}$. Physical and psychological stresses can induce a wide range of immunological alterations in the cell mediated and humoral immunity ${ }^{3,4}$

Although the basic neurochemistry of the stress response is now well understood, much remains to be discovered about how the components of this system interact with one another, in the brain, and throughout the body ${ }^{5}$.

Both negative and positive stressors can lead to stress. The intensity and duration of stress changes, depending on the circumstances and emotional condition of the person suffering from it and examples of stressors ranges from sensory input such as pain, to life experiences such as poverty. Besides releasing typical stress metabolites, characteristic enzymes and hormones, primary factors of psychological stress situations, possible reactions and recognizable symptomatic organic changes also show multi-factorial appearances3. Exposure to psychological stressors can modulate the primary antibody response and increased permanent stress levels can lead to pathological organ changes, psychological alterations as well as psychosomatic diseases ${ }^{6}$.

Mild stress is beneficial in terms of cognitive tasks and performance while higher level of stress which is persistent leads to anxiety and depression ${ }^{7}$. Need to perform in the academic examinations for better carrier prospects acts as an acute stressor to the students ${ }^{8}$. Any type of stress physical or mental causes increase activity of Hypothalamo-PituitoryAdrenal axis leading to increased secretion of cortisol in the plasma9. As the level of stress affects the performance of the students in examination which could in turn become a stressor producing ill effect on the body and mind.

Since serum cortisol has similar primary structure (cyclopentanoperhydrophenanthrene ring system) as steroids 
and lipids, and lipids are usually metabolized to release energy, there may be a possibility of examination stress affecting the lipid profile in the body. Any alteration in the plasma lipid which leads to increase in cardiac risk factor may ultimately predispose the student to risk. Thus the present study is being undertaken to explore the effect of examination stress and to estimate and correlate serum cortisol with lipid profile before \& during the examination in first MBBS students.

\section{Materials and Methods:}

A longitudinal follow up study was done on 50 first MBBS students of Prathima medical college after taking informed consent. The ethical clearance was obtained from institutional ethical committee of Prathima medical college and hospital. Subjects were assessed for stress parameters and serum cortisol at two times. One in the relaxed state (with no examinations i.e., 4 weeks before examination) and other in the stressed state (during theory examination).

Subjects were 18-25 years and matched for age and sex.

Inclusion criteria:

MBBS students of $18-25$ years

Non - smokers

Non - alcoholics

Subjects who stay in the hostel

Exclusion criteria:

People who do not play sports or any athletic activity

People with any history of physical or mental illnesses

Students with the psychiatric disorders, endocrinological disorders, addicted to tobacco or alcohol and having past and family history of diabetes mellitus and hypertension or any subject taking regular medicine were excluded.

Stress parameters of the subjects were assessed with a given questionnaire of 42 items for scoring Depression, Anxiety and Stress Scale (DASS-42), which has 14 questions each for assessing depression, anxiety and stress levels10. Subjects before collection of blood were instructed not to take any food in the morning.

Subjects were made to relax before sample collection. Blood samples were collected between 10 and 11 am in both the conditions to avoid diurnal variations. Samples consist of $5 \mathrm{mls}$ of venous blood collected aseptically from antecubital vein and dispensed into plain bulb and were transported to the lab in ice pack, centrifuged immediately using centrifuge and an aliquot of the separated sera stored frozen $\left(-20^{\circ} \mathrm{C}\right)$ unti analyzed within 48 hours, for cortisol levels. The rest were stored at $4^{\circ} \mathrm{C}$ for the estimation of lipid profile within 48 hours. Both samples and reagents were brought to room temperature before analysis.

The method of Fossati and Prencipe ${ }^{11}$ and McGowan et al $^{12}$ which involve the enzymatic hydrolysis of triglyceride to glycerol was employed in triglyceride estimation. The enzymatic colorimetric method by Allain et $\mathrm{al}^{13}$ was employed for cholesterol estimation. HDL-cholesterol was assayed using the method of Burnstein et al, ${ }^{14}$.

LDL-Cholesterol and VLDL-Cholesterol were calculated from the results of total cholesterol, HDL-cholesterol and triglycerides as recommended by Friedwald et al ${ }^{15}$ and National Cholesterol Education Programme16. Serum cortisol was assayed by ELISA technique ${ }^{14}$.

\section{Statistical analysis:}

Statistical analysis of results obtained was done with the consultation of our college statistician by using SPSS 16 software. $p<0.05, p<0.01$ was considered statistically significant, $p<0.001$ was considered highly significant (HS) and p> 0.05 was considered as not Significant. Serum cortisol levels were correlated with lipid profile using Pearson's co- relation co-efficient $(r)$ method.

\section{Results:}

Table 1:

Comparison of age, serum cortisol, lipid profile levels of the students before \&during examination stress

\begin{tabular}{|c|c|c|c|c|}
\hline Parameters & $\begin{array}{c}\text { Before } \\
\text { examination } \\
\text { Mean } \pm S D(n=25)\end{array}$ & $\begin{array}{c}\text { During examination } \\
\text { Mean } \pm S D \\
(n=25)\end{array}$ & T-Value & P Value \\
\hline Age(years) & $19.56 \pm 1.23$ & $19.5 \pm 2.24$ & 0.300 & 0.74 (NS) \\
\hline Cortisol(ng/ml) & $71.86 \pm 22.43$ & $220.21 \pm 87.41$ & -11.17 & $0.000 * * *$ \\
\hline Total cholesterol(mmol/l) & $103.78 \pm 15.69$ & $128.48 \pm 24.04$ & -4.80 & $0.000 * * *$ \\
\hline $\mathrm{HDL}(\mathrm{mmol} / \mathrm{l})$ & $32.66 \pm 6.90$ & $47.96 \pm 3.03$ & -15.07 & $0.000 * * *$ \\
\hline $\mathrm{LDL}(\mathrm{mmol} / \mathrm{l})$ & $46.26 \pm 18.05$ & $59.84 \pm 22.26$ & -2.97 & $0.05^{* *}$ \\
\hline VLDL(mmol/l) & $33.28 \pm 17$ & $18.5 \pm 17$ & 4.44 & $0.000 * * *$ \\
\hline
\end{tabular}




\begin{tabular}{|l|l|l|l|l|}
\hline Triglycerides(mmol/l) & $125.26 \pm 66.80$ & $83.68 \pm 39.90$ & 4.38 & $0.000^{* * *}$ \\
\hline $\mathrm{p}>0.05:$ Not Significant(NS), $* \mathrm{p}:<0.05:$ Significant(S), \\
$* * \mathrm{p}:<0.01$ : Highly significant(HS), $* * * \mathrm{p}:<0.001$ : Very highly significant. \\
\hline
\end{tabular}

Table 2:

Correlation between serum cortisol and lipid profile values before and during examination stress.

\begin{tabular}{|l|l|c|c|c|}
\hline \multirow{2}{*}{} & \multicolumn{2}{|c|}{ Before examination } & \multicolumn{2}{c|}{ Before examination } \\
\cline { 2 - 5 } & \multicolumn{1}{|c|}{ r-value } & p-value & r-value & p-value \\
\hline Total cholesterol(mmol/l) & 0.001 & 0.9 & 0.21 & 0.1 \\
\hline HDL(mmol/l) & 0.07 & 0.6 & -0.07 & 0.6 \\
\hline LDL(mmol/l) & 0.08 & 0.5 & 0.14 & 0.3 \\
\hline VLDL(mmol/l) & 0.07 & 0.6 & -0.007 & 0.9 \\
\hline Triglycerides(mmol/l) & 0.29 & 0.03 & -0.29 & 0.08 \\
\hline
\end{tabular}

\section{Discussion:}

In the current study, we observed the hypothesis that examination stress may lead to increase in stress hormone, change in plasma lipid profile and that there may be a non significant relationship between cortisol and the lipid profile parameters.

The results in table-1 showed significantly increased serum cortisol levels, total cholesterol, HDL-cholesterol and LDL-cholesterol( $P=0.001,0.001,0.001,0.005$ and 0.001, respectively) during examination when compared to the before examination period. This indicates an increase cortisol and lipids as a result of the ongoing examination.

We also tested the hypothesis that there may be a non significant positive correlation between cortisol and the other parameters before examination stress. This shows that the students were exposed to stress and abnormal lipid profile even before the examination period, probably due to the thought of the impending examination which exposes the students to stress before the actual examination.

The relationship obtained may actually not be connected to the examination since it did not manifest during the examination period. However no statistically significant relationship was observed between cortisol and the other parameters studied both before and during examination stress. This did not support the findings of Roy et al ${ }^{17}$ who had shown unfavourable relationship between high stress cortisol and lipid profile levels.

The observed increase in plasma cortisol may be as a result of stimulation of the ACTH secretion by the stress stimuli which stimulated the synthesis of cortisol precursors 18 . In response to a stressor, neurons with cell bodies in the paraventricular nuclei of the hypothalamus secrete corticotrophin releasing hormone ( $\mathrm{CRH}$ ) and argininevasopressin (AVP) into the hypophyseal portal system ${ }^{19,20}$. The $\mathrm{CRH}$ through the HPA then activates the pituitary and adrenal glands which is supported by Burtis $\mathrm{C}$ et al, Sabyasachi S et al and Tsigos $\mathrm{C}$ et $\mathrm{al}^{18,19}$.

According to Shamsdin SA et al., these interactions can bring changes in immune system leading to increase susceptibility to infection and certain diseases such as psoriasis $^{21}$.

In this study increased cortisol secretions, TC, LDL and HDL were observed during examination stress. Over secretion of stress hormones may also affect the brain where memories are processed and stored, and might cause hormonal and metabolic changes which contribute to heart disease and other health problems. Similar reports were given by Glavas MM et al and Sauro MD et $a^{22,23}$

Since over secretion of stress hormones may also affects the outcome of their examination performance. The examinations studies may not actually be a true test of knowledge of these set of stressed students. In current study the excessive response to stress observed during examination may be as a result of fear associated with the examination. This may also be linked to the warning and knowledge of the fate of the past students who did not excel in the previous similar examinations. It may also be observed that some students were never ready for the respective examinations as a result of not being serious with their studies until examination date is announced. Such students study under severe stress, and are always afraid of examinations. 
According to Qureshi et $\mathrm{al}^{24}$ and Viner ${ }^{25}$ stress also increases visceral fat.The observed non significant positive correlation between increased cortisol during the examination period was in agreement with the study by Weekes et al., ${ }^{26}$ who reported no significant correlations in cortisol and elevations in psychological stress measures. Although serum cortisol has similar primary structure (cyclopentano perhydro phenanthrene ring system) as lipids, the abolition of norma physiological control mechanism observed in examination stress did not relate to the serum concentration of these parameters.

\section{Conclusion:}

This study mainly aims to explore the effect of examination stress on first MBBS students'serum cortisol level and its correlation with lipid profile. The current study showed significant increase in cortisol, TC, HDL and LDL but no significant correlation between cortisol and the other parameters during examination stress.. This may be as a result of physiological compensatory mechanisms. This study gives message to the teachers, that they need continuous assessment of students which helps to reduce risk associated with examination stress. To the students, this study could be helpful in planning strategies to be adopted to cope up the examination stress among medical students.

\section{REFERENCES}

1. Pruessner JC, Gaab J, Hellhammer DH, Lintz D, Schommer $\mathrm{N}$, Ki rschbaum $\mathrm{C}$. Increasing corre lat ions between persolality traits and cortisols responses obtained by data aggregation. Psychoneuroendocrinology 1997; 22:615625

2. Cuttilan AN, Sayampanathan AA, Ho RC. Mental health issues amongst medical students in Asia: a systematic review [2000-2015]. Ann Transl Med 2016;4(4):72.

3. Schore A. Affect Regulation \& the Repair of the Self. New York: W.W. Norton; 2003. ISBN 0393704076. [ Google Scholar]

4. PaderJA, Homar AC. Student stress in clinical practice for nurses. Rev Enferm. 2006;29:19-24.[PubMed][Google Scholar]

5. Keil RMK. Coping and stress: a conceptual analysis. J Adv Nursing. 2004; 45:659-665. [Pub Med][Google Scholar].

6. Moraska A, Campisi J, Nguyen KT, Maier SF, Watkins LR, Fleshner M. Elevated IL-1beta contributes to antibody suppression produced by stress. J Appl Physiol. 2002;93:207-215.[PubMed][Google Scholar]

7. Singh R, Goyal M, Tiwari S, Ghildiyal A, Nattu S, Das S. Effect of Examination stress on mood, performance and cortisol levels in medical students. Indian J Physiol Pharmacol2012; 56 (1):48-55.

8. McEwen BS. Protective and damaging effects of stress mediators. N Engl J Med 1998; 338: 171-179.

9. Kirschbaum C, Hellhammer DH. Salivary cortisol in psychoneuroendocrine research: recent developments and appl i cat ions. Psychoneuro endoc rinology 1994; 19: 313-333.

10. Lovibond SH, Lovibond PF. (1995). Manual for the Depression Anxiety Stress Scales (2nd ed.).Sydney: Psychology Foundation

11. Fossati P, Prencipe L. Serum triglycerides determined colorimetrically with an enzyme that produces hydrogen peroxide. Clinical Chemistry. 1982;28:2077-2080.[Pub Med][Google Scholar]

12. McGowan MW, Artiss JD, strandbergh DR, Za P. Peroxidase-coupled method for the colorimetric determination of serum triglycerides. Clinical Chemistry. 1983;29:538-542.[Pub Med]

13. Allain CC, Poon LS, Chan CSG, Richmond W, FU PC. Enzymatic determination of total serum cholesterol. Clinical Chemistry. 1974; 20:470-475.

14. Burnstein M, Scholnick HR, Morfin R. Rapid method for the isolation of lipoproteins from human serum by precipitation with polyanions. Scand J Clinical Lab Invest. 1980; 40:583-595.

15. Friedewald WT, Levey RT, Fredrick DS. Estimation of concentration of LDL-Cholesterol without the use of preparative ultracentrifuge. Clinical Chemistry. 1972; 18:499-509.

16. National Cholesterol Education Programme, NCEP Summary of the second Report of the National Cholesterol Education Programme (NCEP) expert, author. Panel on detection and treatment of high blood cholesterol in adults. JAMA. 1993; 269:3015-3023.

17. Roy MP, Kirschbaum C, Streptoe A. Psychological, cardiovascular and metabolic correlates of individual differences in cortisol stress recovery in young men. Psychoneuroendocrinology. 2001; 26:375-391.

18. Burtis C, Ashwood AR, Aldrich JE. Tietz Fundamentals of Clinical Chemistry. 4th (edn) W.B. Saunders \& Co; 2001. Endocrine hormones; pp. 780-794. [Google Scholar]

19. Sabyasachi S. Medical Physiology. Thieme Publishing Group; 2007. pp. 536-546.[Google Scholar] 
20. Tsigos C, Chrousos GP. Hypothalamic-pituitary-adrenal axis, neuroendocrine factors, and stress. Journal of Psychosomatic Research. 2002; 53:865-871. [Pub Med][Google Scholar]

21. Shamsdin SA, Anvar M, Mehrabani D. The effect of exam stress on IL-6, cortisol, CRP and IgE levels. Iranian Red Crescent Medical Journal. 2009;12:484-488.

22. Glavas MM, Weinberg J. Stress, Alcohol Consumption, and the Hypothalamic-Pituitary-Adrenal Axis. In: Yehuda S, Mostofsky DI, editors. Nutrients, Stress, and Medical Disorders. Ottowa, NJ: Human Press; 2006. pp. 165183.[Google Scholar]

23. Sauro MD, Jorgensen RS, Pedlow CT. Stress, glucocorticoids and memory: a meta-analytic review. Stress. 2003;6:235-245. [Pub Med][Google Scholar]

24. Qureshi GM, Seehar GM, Zardari MK, Pirzado ZA, Abbasi SA. Study of blood lipids, cortisol and haemodynamic variations under stress in male adults. J Ayab Med Coll Abbottabab. 2009;21:158-161.[PubMed][Google Scholar]

25. Viner R. Putting Stress in Life: Hans Selye and the Making of Stress Theory. Social Studies of Science. 1999; 29:391410.

26. Weekes N, Lewis R, Patel F, Garrison-Jakel J, Berger DE, Lupien SJ. Examination stress as an ecological inducer of cortisol and physiological responses to stress in undergraduate students. Stress. 2006; 9(4):199-206.

How to cite this article : Padmaja Rao T. Correlation between lipid profile and serum cortisol during examination stress among I MBBS students. Perspectives in Medical Research 2020; 8 (2):10-14 DOI : 10.47799/pimr.0802.05

Sources of Support: Nil, Conflict of interest: None declared 